http://www.moderntechno.de/index.php/meit/article/view/ge4-013

DOI: $10.30890 / 2567-5273.2018-04-02-013$

\title{
УДК 635.63:631.526.3.006.83
}

SUITABILITY FOR PROCESSING OF CUCUMBER FRUIT

DIFFERENT HYBRIDS DEPENDING ON THE DEGREE OF RIPENESS ПРИДАТНІСТЬ ДО ПЕРЕРОБКИ ПЛОДІВ ОГІРКА РІЗНИХ ГІБРИДІВ ЗАЛЕЖНО ВІД СТУПЕНЯ СТИГЛОСТІ

Zavadska O. / Завадська О.В. c.a.-g.s. as.prof/к. c.-2.H., доu. НУБіП Украӥни, м. Київ, вул. Героїв Оборони, 13, 03041 NULES of Ukraine, Kiev, Geroïv Oborony,13, 03041

Ilyuk N. / Ілюк Н.A. c.a.-g.s./к. c.-2.H., Відкритий міжнародний університет розвитку людини «Украйна» Open International University of Human Development «Ukraine»

Анотація. Переробка плодів огірка залишається й на сьогодні ефективним способом консервування, який забезпечує отримання корисної продукиї. Якість свіжої та переробленої продукиії огірка значно залежить від сортових особливостей та ступеня стиглості плодів. Наведено результати вивчення основних біохімічних, біометричних та органолептичних показників свіжої $i$ солоної продукції огірка, вирощуеного в умовах Лісостепу, залежно від гібриду та розміру плодів. Виявлено найпридатніші для переробки варіанти.

Ключові слова: огірок, гібрид, плід, якість, дегустачія, біохімічні показники, переробка, соління, розмір плоду

Вступ. Огірок $є$ стратегічною овочевою культурою для України. Незважаючи на те, що його частка у валовому зборі основних овочевих культур у країні не перевищує 11-12 \%, дефіцит плодів негативно впливає на роботу всієї консервної промисловості України [1]. Основною проблемою внутрішнього ринку овочів $є$ збереження врожаю та повного забезпечення потреб споживчого ринку впродовж всього року [3]. Одним із альтернативних джерел отримання всієї користі від огірків є споживання переробленої, зокрема й солоної продукції.

Одержання перероблених плодів огірка високої якості залежить від правильного підібраного сорту. Сортимент огірка великий та інтенсивно зростає щороку, що говорить про популярність цієї культури, як за поширенням, так і споживанням [1,3].

У процесі переробки в сировині відбуваються різноманітні біохімічні перетворення, які при неправильній технології можуть викликати погіршення харчової цінності продукції i навіть їх псування. Якісну консервовану продукцію можна отримати тільки з урахуванням технологічних особливостей сировини, які, у свою чергу, залежать від розміру та ступеня стиглості плодів.

Методика досліджень. Для досліджень було відібрано два гібриди огірка, придатних для соління та занесених до Реєстру сортів рослин. Для встановлення впливу розміру плодів на якість свіжої та переробленої продукції плоди дослідних сортів ділили на фракції (згідно вимог діючого стандарту): корнішони першої групи - 5,1-7,0 см; корнішони другої групи - 7,1-9,0 см, зеленці - 9,1-11,0 см. Як контроль для обох сортів вибрали зеленці, довжина 
плодів яких становила 9,1-11,0 см [4]. Схема досліду наведена у табл.1. Плоди дослідних сортів вирощували на території дослідного овочевого поля НУБіП України. Аналізи свіжої й солоної продукції та безпосередньо дослідне соління здійснювали в умовах науково-навчальних лабораторій кафедри технології зберігання, переробки та стандартизації продукції рослинництва ім. проф. Б.В. Лесика за загальноприйнятими методиками. Для соління плодів завчасно готували 5-8 \% концентрації розсіл залежно від їх розміру [2].

Результати досліджень. Придатність плодів огірка до переробки значно залежить від вмісту основних біохімічних показників (табл. 1). За період вегетації у плодах дослідних сортів накопичувалося 4,1-5,2 \% сухої речовини. Найменше сухої речовини в плодах обох сортів накопичувалося у контрольних варіантах (плодів довжиною 9,1-11,0 см) Біднішим біохімічним складом характеризувалися плоди гібриду Кріспіна $\mathrm{F}_{1}$. Зі збільшенням довжини плоду вміст сухої речовини зменшувався.

Вміст цукрів у плодах досліджуваних сортів коливався у межах від 1,8 до $2,8 \%$. Встановлена пряма суттєва залежність між вмістом сухої речовини та цукрів $(\mathrm{r}=+0,98 \pm 0,02)$ і обернена середня між масою плоду та вмістом сухої речовини $(\mathrm{r}=-0,38 \pm 0,03)$.

Таблиця 1

Основні показники якості свіжих плодів огірка, середне за 2016-2017 рр.

\begin{tabular}{|c|c|c|c|c|c|c|}
\hline \multirow[b]{2}{*}{ Розмір плодів, см } & \multicolumn{3}{|c|}{ Вміст у плодів } & \multicolumn{2}{|c|}{$\begin{array}{c}\text { Біометричні } \\
\text { показники плодів }\end{array}$} & \multirow{2}{*}{$\begin{array}{c}\text { Дегуста- } \\
\text { ційна } \\
\text { оцінка, } \\
\text { бал* }\end{array}$} \\
\hline & $\begin{array}{c}\text { сухої } \\
\text { речовини, } \\
\%\end{array}$ & $\begin{array}{c}\text { цукрів } \\
\text { (сума), } \\
\%\end{array}$ & $\begin{array}{c}\text { вітаміну C, } \\
\text { мг\% }\end{array}$ & мaca, $\Gamma$ & $\begin{array}{c}\text { діаметр, } \\
\text { мм }\end{array}$ & \\
\hline \multicolumn{7}{|c|}{ Кріспіна $\mathrm{F}_{1}$} \\
\hline 9,1-11,0 (контроль) & 4,1 & 1,8 & 10,8 & 80,3 & 45,2 & 4,4 \\
\hline $7,1-9,0$ & 4,4 & 2,0 & 11,4 & 63,2 & 33,0 & 4,7 \\
\hline $5,1-7,0$ & 4,7 & 2,2 & 13,0 & 50,4 & 23,4 & 4,7 \\
\hline $\mathrm{HIP}_{05}$ & 0,3 & & & 0,6 & & \\
\hline \multicolumn{7}{|c|}{ Наташа $F_{1}$} \\
\hline 9,1-11,0 (контроль) & 4,8 & 2,3 & 13,4 & 91,4 & 49,0 & 4,5 \\
\hline $7,1-9,0$ & 4,9 & 2,6 & 14,2 & 73,2 & 35,4 & 4,7 \\
\hline $5,1-7,0$ & 5,2 & 2,8 & 15,8 & 57,8 & 61,2 & 4,8 \\
\hline $\mathrm{HIP}_{05}$ & 0,6 & & & 1,3 & & \\
\hline
\end{tabular}

* за 5-бальною шкалою

Кількість вітаміну $\mathrm{C}$, що накопичувалася у плодах огірка, значно залежала як від сорту, так і від розміру плодів. В обох варіантах більше цього елемента виявлено у плодах меншої довжини.

За результатами дегустаційної оцінки всі плоди отримали досить високі оцінки - від 4,3 до 4,8 бала за 5-бальною шкалою. Вищі оцінки були у корнішонів порівняно із зеленцями.

Для споживачів важливе значення має поживна та біологічна цінність переробленої продукції. Вміст основних біохімічних показників у солоних 
плодах огірка та у розсолі наведено у табл. 2.

У процесі ферментації значно змінювався біохімічний склад огірків та заливки. Вміст сухої речовини зростав, порівняно зі свіжими плодами, на 36$43 \%$. Накопичувався вміст органічних кислот, у всіх дослідних варіантах зростала кислотність і коливалася у межах 0,99-1,23 \%.

Таблиця 2

Біохімічний аналіз та дегустаційна оцінка консервів «Огірки солоні», виготовлених із плодів різних сортів та розміру (після 6 місяців зберігання)

\begin{tabular}{|c|c|c|c|c|c|c|}
\hline \multirow[b]{2}{*}{$\begin{array}{c}\text { Розмір } \\
\text { плодів, } \\
\text { см }\end{array}$} & \multirow[b]{2}{*}{$\begin{array}{c}\text { Вид } \\
\text { продукту }\end{array}$} & \multicolumn{4}{|c|}{ Вміст у плодах } & \multirow{2}{*}{ 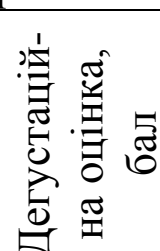 } \\
\hline & & $\begin{array}{c}\text { сухої } \\
\text { речовини, } \\
\%\end{array}$ & $\begin{array}{c}\text { титрова- } \\
\text { них } \\
\text { кислот, \% }\end{array}$ & $\begin{array}{c}\text { цукрів } \\
\text { (сума), \% }\end{array}$ & $\begin{array}{c}\text { вітаміну C, } \\
\text { мг\% }\end{array}$ & \\
\hline \multicolumn{7}{|c|}{ Кріспіна $F_{1}$} \\
\hline \multirow{2}{*}{$\begin{array}{c}9,1-11,0 \\
\text { (контроль) }\end{array}$} & огірки & 6,0 & 1,06 & 0,52 & 7,62 & \multirow{2}{*}{4,0} \\
\hline & розсіл & 5,9 & 1,07 & 0,52 & 7,00 & \\
\hline \multirow{2}{*}{$7,1-9,0$} & огірки & 6,3 & 1,10 & 0,55 & 8,43 & \multirow{2}{*}{4,7} \\
\hline & розсіл & 6,3 & 1,03 & 0,54 & 8,30 & \\
\hline \multirow{2}{*}{$5,1-7,0$} & огірки & 6,5 & 1,20 & 0,57 & 9,80 & \multirow[t]{2}{*}{4,8} \\
\hline & розсіл & 6,4 & 1,20 & 0,55 & 9,80 & \\
\hline \multicolumn{7}{|c|}{ Наташа $\mathrm{F}_{1}$} \\
\hline \multirow{2}{*}{$\begin{array}{c}9,1-11,0 \\
\text { (контроль) }\end{array}$} & огірки & 6,5 & 0,99 & 0,55 & 9,00 & \multirow{2}{*}{4,3} \\
\hline & розсіл & 6,4 & 1,00 & 0,54 & 9,00 & \\
\hline \multirow{2}{*}{$7,1-9,0$} & огірки & 6,9 & 0,95 & 0,58 & 10,72 & \multirow{2}{*}{4,8} \\
\hline & розсіл & 7,0 & 0,94 & 0,58 & 10,70 & \\
\hline \multirow{2}{*}{$5,1-7,0$} & огірки & 7,0 & 1,01 & 0,61 & 12,34 & \multirow{2}{*}{4,9} \\
\hline & розсіл & 6,9 & 1,00 & 0,61 & 12,00 & \\
\hline
\end{tabular}

Цукри використовуються під час бродіння молочнокислими бактеріями і вміст їх у солоній продукції зменшувався на 70-75 \% порівняно з початковим. Вміст вітаміну $\mathrm{C}$, порівняно зі свіжою продукцією, знижувався на 23-33 \%. Найвищою біологічною цінністю після 6 місяців зберігання характеризувалася продукція, виготовлена із корнішонів першої групи (довжина плодів 5,1-7,0 см) гібриду Наташа $\mathrm{F}_{1},-$ вміст вітаміну $\mathrm{C}$ був на рівні 12,34 мг \%.

Найвищими органолептичними показниками, як відразу після ферментації, так і після шести місяців зберігання, характеризувалися корнішони першої групи (розмір плодів 5,1-7,0 см) гібриду Наташа - 4,8 бала. Зеленці обох дослідних сортів за результатами дегустації були віднесені до другого товарного сорту через м'яку консистенцію плодів.

Висновки. За біометричними показниками плоди всіх дослідних варіантів відповідали вимогам діючого стандарту і були придатними для соління. Більшою харчовою та біологічною цінністю характеризуються плоди гібриду Наташа $\mathrm{F}_{1}$. Вміст основних біохімічних показників значно залежить від розміру плодів. Більша кількість сухої речовини, цукрів, аскорбінової кислоти та нітратів нагромаджується у плодах меншого розміру. 
Для отримання якісної, біологічно цінної солоної продукції огірка доцільно використовувати корнішони першої та другої груп (довжина плодів $5,1-9,0$ см).

\section{Література:}

1. Бобось I.М.Технології вирощування огірка для переробки: Монографія / I.М. Бобось, О.В. Завадська. - К.: «ЦП «Компринт», 2017. - 208 с.

2. Скалецька Л.Ф. Методи наукових досліджень зі зберігання та переробки продукції рослинництва: навчальний посібник / Л.Ф. Скалецька, Г.І. Подпрятов, О.В. Завадська. - К.: ЦП «Компринт», 2014. - 416 с.

3. Skaletska L.F. Selection of carrots varieties for storage and processing // L.F. Skaletska, O.V. Zavadska // SWorld Journal “Scientific world”, Ivanovo, 2015. Vol.J11510. - October, 2015.

Abstract. The processing of cucumber fruit remains an effective way of preserving, which provides the obtaining of useful products. The quality of fresh and processed cucumber products depends on the varietal characteristics and degree of fruiting.The article presents the results researches of biochemical, organoleptic, trade, technological indexes of fresh and cucumber's products, which has been grown up in conditions of Forest-steppe, depending of variety and size of fruit. The most suitable options for processing are found.

Key words: cucumber, hybrid, fruit, quality, tasting, biochemical indicators, processing, pickles, size of fruit.

\section{References:}

1. Bobos' I.M.Tekhnolohiyi vyroshchuvannya ohirka dlya pererobky: Monohrafiya / I.M. Bobos', O.V. Zavads'ka. - K.: Komprynt, 2017. - 208 p.

2. Skaletska L., Podpryatov G., Zavadska O. Metody naukovykh doslidzhen' zi zberihannya ta pererobky produktsiyi roslynnytstva [Bases of scientific researches in storage and processing plant products: study guide]. - K.: Komprynt, 2014. - 416 p.

3. Skaletska L.F. Selection of carrots varieties for storage and processing // L.F. Skaletska, O.V. Zavadska // SWorld Journal "Scientific world", Ivanovo, 2015. - Vol.J11510. - October, 2015.

Стаття відправлена 09.06.2018 p.

(C) Завадська О.В. Ілюк Н.А. 